\title{
Jensen mellem gengangere
}

Stefan Iversen: Den uhyggelige fortælling - unaturlig narratologi og Johannes V. Jensens tidlige forfatterskab. Aarhus: Aarhus Universitetsforlag 2018, 374 sider, 299 kr.

Madame D’Ora er den af Johannes V. Jensens bøger, der gør mest i spiritisme, men uhyggelig er den ikke, det er derimod Kongens Fald. I hvert fald i henhold til det begrebsapparat, som Stefan Iversen benytter sig af i Den uhyggelige fortælling - med undertitlens varedeklaration: "Unaturlig narratologi og Johannes V. Jensens tidlige forfatterskab", baseret vistnok på en ph.d.-afhandling med flere år på bagen.

Unaturlig narratologi leder tanken hen på Monika Fluderniks 1996-bog om naturlig narratologi, som da også er en afgørende inspirationskilde. Det unaturlige er her ikke i modsætning til, men ligger i forlængelse af det naturlige. Teoridannelsen er under udvikling, og Iversen vil tydeligvis yde et bidrag, og gør det. En anden inspiration udgår fra Jacques Derridas måske lidt løseligt henkastede betragtninger over Freuds begreb om det uhyggelige, "det fortrængtes genkomst". Grebet består altså i "at bedrive unaturlig narratologi ved at kombinere indsigter fra den naturlige narratologi med indsigter fra Derridas praksis”. Det er ikke en ukompliceret affære. Halvdelen af Iversens bog beskæftiger sig med teori og metode, begrebsudvikling og begrebsafklaring; f.eks. er et halvt hundrede sider afsat til Derrida-overvejelserne.

Ikke at Johannes V. Jensen helt glimrer ved sit fravær i denne del. Iversen griber "som optakt" til den meget tidlige tekst "En, der kom udenfor det hele", kun optrykt én gang, af Niels Birger Wamberg i Hos Fuglene. Men da han løber tør for analyseredskaber, henlægges den. Han har også et kapitel om "Vendingen", der på basis af receptionstekster udforsker det for så vidt "kendte" problem om overgangen fra "tidlig Jensen" knyttet til negativitet til "sen Jensen" knyttet til positivitet, med Jørgen Elbeks berømte formulering: "fra sublim nihilisme til positivitet af lavere orden”, eller i Hans Otto Jørgensens 2015-formulering: det hele blev "fyret af" på 10-15 år. Overgangen fra genialsk vildskab til klassisk modenhed kan opfattes anderledes, ripeness is all. Eller man kan som Lars Handesten insistere på "en mere nøgtern og uhildet fremstilling”, eller som Poul Houe begive sig ind i de sene, "afklarede" værker og finde brudflader dér. Wamberg har bemærket, at "lysets og mørkets magter" brydes overalt i forfatterskabet. Iversen antyder, at uklarheden kan have at gøre med opfattelsen af teksterne som autonome eller som psykologiserende indholdsomskrivninger.

Men hvad er det så, der gør en fortælling uhyggelig? Som anført: Madame D’Ora falder udenfor, derom handler kapitlet "Genfærdet forsvinder". Uhyggen holdes i ave, fordi 
der er styr på udsigelsen. Når der ikke er styr, når der er taletvivl, spidser det til. Nogle, f.eks. Aage Schiøttz-Christensen, finder ganske vist opgøret mindre helhjertet, men Iversen lægger sig i sporet efter Frits Andersens karakteristik af romanen som "et selvironisk mesterstykke i skyggeboksning" og læser Edmund Hall som en "maskulin, analytisk abstraktion" og Madame D’Ora som "feminin, parfumeret kødfylde", som videnskabsmanden og kunstneren, begge "specialiserede ud af livsdueligheden". Og de spiritistiske seancer er jo blot svindel og humbug.

Kongens Fald, derimod! Det er en uhyggelig fortælling, og til læsningen af den kommer vi følgelig via analyser af flere mindre tekster, der skal stemme den kritiske bevidsthed, tekster, som altså er uhyggelige og egnede til at gøre det tydeligere, hvad begrebet indebærer. Det drejer sig om den allerede nævnte sære tekst om den støj-og-vanvidsramte mand, der slutter showet ved at tage stryknin. Spørgsmålet er: hvem taler her? Iversen pusler med ideen om et selvbiografisk moment, men hører også et intertekstuelt ekko af Edgar Allan Poes “The Tell-Tale Heart” (1843). Den komplicerede analyse resulterer i en enkel konstatering: "Teksten er en besværgelse; skrevet på just den sensibilitet, den forsøger at tage livet af." Men her lyder en genkommende formulering: den uhyggelige (skriftbårne) fortælling karakteriseres ved, at "tvivlen om, hvem der taler, er genkommende for både de fremstillede personer og læseren".

Også Johannes Jørgensen udgjorde en arvepart, som Jensen beflittede sig på at uddrive. Som bekendt ekspederede han sine to første romaner over i Jørgensens symbolistiske forfatterskab. Her er det kortteksten "Gura”, der holdes op mod romanen En Fremmed - og karakteriseres som "fortællingen om et jegs forsvinden i og med jegets fortælling om sin forsvinden".

Også Jensens bidrag til enqueten i Julealbum 1900 om overnaturlige tildragelser omtales. Her er det Hamlet, som Iversen bringer i fokus - således som Jensen oftere gør det. Enquetens motto er prinsens berømte ord til Horatio, "There are more things ..." (som redaktionen vel har hentet frem på netop Jensen-bidragets foranledning). Eksemplerne skal med digterens ord vise, at "Rædslen opstaar og stiger ved en Vekselvirkning mellem Fornemmelse og Forestilling”, i forhold til hvilke fortælleakten kan indgå på forskellig vis. Ved Hamlets genkomst i 1920'erne var det i kraftigere repræsentationer: "Ur-Hamlet", Saxos version, og "Amloden”, den mundtlige fortælletraditions version. I Hamletoversættelsen udelades "de tilfældige træk", angiveligt fremkommet ved, at Shakespeare har brugt Essex-jarlen Devereux som model.

De analyserede tidligtekster udviser, på forskellig vis, tvivl om, hvem der fører ordet. Det lykkes at fremmane, men ikke at uddrive, for nu at referere til en af Jensens centrale operationer. Det gælder også "Rovdyr i Sne", hvor Iversen på grund af genreopløsningen knap nok får trukket en pointe ud, og "Fra Christiania-Cirkus", som leger kispus med læserens konventionsbestemte forventninger; jeget positionerer sig f.eks. som afsender, men er det ham, som er dræberen?

Endelig omtales kort myten "Knokkelmanden" (som oprindeligt var todelt på grund af en avisredaktionel disposition) - og nu netop som oplæg til en omfattende og dybtborende gennemgang af stemmetvivlen i Kongens Fald (altså som uhyggelig fortælling). Som det vedgås, er der tale om en ensidigt fokuseret analyse. Indledningsvis opsøges grundlæggende forskelligheder i et fåtal estimerede tolkninger, fra Sven Møller Kristensens, der vil læse romanen nykritisk, men skrider ud i biografismens grøft, til Anders 
Thyrring Andersens, der rejser spørgsmålet, om det er Mikkel eller forfatteren, der er dæmoniseret. Foreligger der med andre ord et afsluttet værk eller en modernitets-symptomatisk diagnose? Spørgsmålet er blevet stillet før. Det nye er, at det nu "gøres til genstand for en samlet, metodisk reflekteret analyse".

I de følgende afsnit endevendes de for synsvinklen mest relevante problemstillinger. De "uhyggelige" træk i deres varierende forhold til "tvivlen om en tales udspring" registreres; f.eks. forfølges kværnlyden frem mod dens kulmination i grottesangen, som jo ikke er forankret i Mikkels bevidsthed; og hvad med dødens ridt? Tvivlen kan også være fremstillingsmæssig. Mikkel og Axel er ikke alene om at være reflektorfigurer; f.eks. er den markante passus om de to grundlæggere af "et Dynasti i det Blaa" auktorialt formidlet, og også brugen af dækket direkte tale bærer ved til tvivlen. En del af bogens fascinationskraft, dens "særlige kvaliteter", skriver sig fra "Jensens særlige blanding af lyrisk apostrofe og prosaisk dækning", hvilket i afsnittet "Den manende apoteose" påvises med inddragelse af en del teori, også angående du-fortællingen.

Endelig mobiliseres dekadencebegrebet, i afsnittet "Produktion af misfostre", dvs. de tre centrale begreber - selvbevidsthed, ekstremisme, adskillelse - i Vladimir Jankélévitchs dekadenceteori.

Kongens Fald er jo ifølge Jørgen Dines Johansen "dekadencens hovedværk i Danmark". Iversen argumenterer for, at bogen kan/bør læses "som en tekst i splid med egne værdier og normer, som et højspændt, uforløst opgør med erfaringer, der betinger dens eksistens". Ganske vist, noterer han forundret, opsøger Dines Johansen ikke "opløsning, adskillelse og splittelse" i bogen. Iversen er også ganske forbeholden over for Dines Johansens harmoniserende kompositionsanalyser og stilbetragtninger og over for den mangel på tvivl om udsigelsen, som netop er hans anliggende. Snarere er det hos Lis Norup, Iversen forankrer sin dekadenceopfattelse. Dekadencen er rent ud sagt ungdomsproduktionens hovedspøgelse og uddrivelsen af den dens hovedanliggende. Der dynges symptomer på bordet. Hvad f.eks. om man læste bogen som "slægtsroman"? Kongens horeunge Carolus er rent intellekt, Mikkels døvstumme barnebarn Ide er ren sansning. Kongens magt kulminerer i en grotesk dekapitering, der leder til afmagt og fald. Og Mikkel er uden evne til at adskille indre og ydre, til at "fastholde, gennemtrumfe og handle", han svinger mellem udadrettede "primitive impulser" og indadrettet "livstruende overfølsomhed".

Stefan Iversen har betænkt os med en teoristærk, perspektivrig, detaljemættet og uhyggeligt omhyggelig indføring i Den Store Jensens tidlige skriftverden. Godt brølt, Jøve! 